\title{
Pengaruh Lingkungan Kerja Terhadap Kinerja Tenaga Kependidikan pada Fakultas Matematika dan Ilmu Pengetahuan Alam Universitas Lampung
}

\author{
Yuliana Yamin ${ }^{1 *}$, Nuzleha ${ }^{1}$, Yulisnawati ${ }^{1}$ \\ ${ }^{1}$ Universitas Sang Bumi Ruwa Jurai \\ Correspondence: yuliayamin0607@gmail.com
}

\begin{abstract}
Abstrak.
Penelitian ini bertujuan untuk mengetahui pengaruh lingkungan kerja terhadap kinerja tenaga kependidikan Fakultas Matematika dan Ilmu Pengetahuan Alam (FMIPA) Universitas Lampung. Metode Penelitian ini menggunakan Kuantitatif Deskriptif. Populasi dalam penelitian ini berjumlah 76 orang tenaga kependidikan. Penentuan sampel menggunakan metode Purposive Sampling sehingga didapat sampel berjumlah 44 orang tenaga kependidikan. Pertama, analisis data menggunakan uji-t untuk menguji hipotesis apakah Lingkungan Kerja (X) berpengaruh terhadap Kinerja Karyawan (Y). Berdasarkan nilai Sig. Pada lingkungan kerja (X) diperoleh sebesar 0,032 lebih kecil dari taraf signifikansi 0,05 sehingga dapat ditarik kesimpulan bahwa ada pengaruh antara lingkungan kerja terhadap kinerja tenaga kependidikan pada Fakultas Matematika dan Ilmu Pengetahuan Alam (FMIPA) Universitas Lampung dan hasil uji koefisien determinasi $\left(\mathrm{R}^{2}\right)$ sebesar 0,105 , sehingga dari nilai tersebut dapat dijelaskan bahwa sebesar 10,5\% kinerja tenaga kependidikan yang ada di Fakultas Matematika dan Ilmu Pengetahuan Alam (FMIPA) Universitas Lampung dipengaruhi oleh lingkungan kerja.
\end{abstract}

Kata kunci: Kinerja Pegawai, Lingkungan Kerja, Tenaga Kependidikan

\begin{abstract}
.
This study aims to determine the effect of the work environment on the performance of the teaching staff of the Faculty of Mathematics and Natural Sciences (FMIPA) at the University of Lampung. This research method uses descriptive quantitative. The population in this study amounted to 76 education personnel. Determination of the sample using the purposive sampling method in order to obtain a sample of 44 education personnel. First, data analysis uses t-test to test the hypothesis whether the Work Environment $(X)$ has an effect on Employee Performance (Y). Based on the value of Sig. In the work environment $(X)$ obtained 0.032 which is smaller than the significance level of 0.05 so it can be concluded that there is an influence between the work environment on the performance of education personnel at the Faculty of Mathematics and Natural Sciences (FMIPA) at the University of Lampung and the results of the coefficient of determination test (R2). ) is 0.105 , so from this value it can be explained that $10.5 \%$ of the performance of education personnel at the Faculty of Mathematics and Natural Sciences (FMIPA) at the University of Lampung is influenced by the work environment.
\end{abstract}

Keywords: Employee Performance, Work Environment, Education Personnel

\section{PENDAHULUAN}

Dalam suatu sistem operasi instansi, potensi sumber daya manusia pada hakikatnya merupakan salah satu modal dan memegang suatu peran penting dalam mencapai tujuan instansi (Budianto \& Katini, 2015). SDM harus dikelola dengan baik untuk meningkatkan produktivitas, efektifitas dan efisiensi organisasi (Ferawati, 2017). Namun, peningkatan produktivitas kerja bukanlah suatu hal yang mudah untuk dilakukan (Aspiyah \& Martono, 2016). Pemimpin maupun karyawan pada pola tugas dan pengawasan merupakan penentu tercapainya tujuan perusahaan, dengan kata lain produktivitas organisasi ditentukan dari kinerja pegawai 
yang dimilikinya (T. S. Siagian \& Khair, 2018).

Kinerja karyawan (job performance) dapat diartikan sebagai sejauh mana seseorang melaksanakan tanggung jawab dan tugas kerjanya (Sunarsi et al., 2020). Kinerja pegawai pada dasarnya adalah hasil karya pegawai selama periode tertentu dibandingkan dengan berbagai kemungkinan, misalnya, standar, target/sasaran atau kriteria yang telah ditentukan terlebih dahulu dan telah disepakati Bersama (Fatria \& Hifnie, 2020). Sumber daya manusia yang baik maka akan menghasilkan kinerja yang baik (Anam \& Rahardja, 2017).

Peningkatan kinerja pegawai dipastikan akan membawa kemajuan bagi organisasi (Josiah, 2020). Apabila di dalam organisasi tersebut terdapat SDM yang handal maka kinerja pegawainya akan tinggi dan tujuan dari organisasi tercapai dengan maksimal (Yamin et al., 2021). Oleh karena itu, Dalam rangka mencapai hasil kinerja yang maksimal, sumber daya manusia membutuhkan faktor pendukung yang perlu diperhatikan yaitu lingkungan kerja (Yuliantari \& Prasasti, 2020).

Kondisi lingkungan kerja dikatakan baik atau sesuai apabila manusia dapat melaksanakan kegiatan secara optimal, sehat, aman, dan nyaman (Farizki \& Wahyuati, 2017). Kondisi lingkungan kerja yang nyaman akan mempengaruhi pegawai bekerja lebih giat dan konsentrasi menyelesaikan tugas-tugasnya sesuai jadwal (Wijaya \& Susanty, 2017). Meskipun lingkungan tidak melaksanakan proses produksi dalam suatu perusahaan, namun Lingkungan Kerja mempunyai pengaruh langsung terhadap prestasi kerja pegawai (Edasa \& Putra, 2015). Lingkungan kerja juga merupakan salah satu bentuk motivasi yang diberikan oleh perusahaan untuk meningkatkan semangat kerja karyawan (Syafrina \& Manik, 2018). Jika pegawai menyenangi lingkungan kerja dimana dia bekerja, maka pegawai tersebut akan betah di tempat kerjanya untuk melakukan aktivitas dan menyelesaikan tugas-tugasnya (Nabawi, 2019).

Penilain kinerja perlu dilakukan untuk perbaikan prestasi kerja, penyesuaian kompensasi, kebutuhan pengembangan, serta melihat penyimpangan maupun kesalahan dalam pekerjaan (Mudayana, 2020). Dalam hal ini, di FMIPA Unila dilakukan penilaian kinerja secara periodic setiap tahunnya dengan berpedoman pada standar-standar nilai yang sesuai dengan PP RI No. 46 Tahun 2011. Hal ini berguna untuk mengetahui dan mengevaluasi pelaksanaan kinerja dan membandingkan dengan rencana kerja serta melakukan tindakan untuk memperbaiki kinerja periode berikutnya (Yamin, 2017).

Hasilnya, ada beberapa pegawai yang tidak dapat menyelesaikan tugas yang diberikan. Pegawai yang memiliki masalah yang seperti ini adalah pegawai yang kurang inisiatif dalam bekerja. Sehingga perilaku pegawai seperti ini dapat menurunkan kualitas kinerja pegawai itu sendiri maupun organisasi.

Fasilitas yang diberikan oleh instansi sudah cukup memadai (Wildayati et al., 2019), tetapi ada yang perlu diperbaiki ataupun ditambah seperti suhu ruangan, kebersihan ruangan, tata letak sarana dan prasarana yang kurang rapi di beberapa ruang termasuk meja antar pegawai yang terlalu berdekatan dan banyaknya dokumen serta barang-barang lain yang diletakkan di sekeliling meja kerja pegawai. Selain itu, belum tersedianya generator listrik yang menghambat pekerjaan apabila terjadi pemadaman listrik (Sambodo et al., 2020).

Sehingga, dari latar belakang di atas dapat disimpulkan bahwa kinerja tenaga kependidikan Fakultas Matematika dan Ilmu Pengetahuan Alam (FMIPA) Universitas Lampung belum maksimal terlihat dari dalam menyelesaikan pekerjaan sesuai dengan waktu yang telah ditentukan, dan masih terdapat karyawan yang tidak dapat menggunakan komputer. Selain itu lingkungan kerja belum mendukung untuk kerja lebih nyaman. 
Sebelumnya, sudah banyak penelitian yang membahas mengenai variabel ini. Antara lain penelitian oleh handayani \& Daulay (2021) mengenai pengaruh lingkungan kerja dan stress kerja terhadap kinerja karyawan studi pada PT Bank Sumut Medan dengan hasil lingkungan kerja berpengaruh positif terhadap kinerja karyawan (Handayani \& Daulay, 2021). Penelitian oleh Susanto \& halim (2020) mengenai pengaruh lingkungan kerja terhadap kinerja karyawan pada PT. Kompas Gramedia Cabang Karawaci dengan hasil Terdapat pengaruh yang positif dan signifikan lingkungan kerja terhadap kinerja karyawan pada PT. Kompas Gramedia Cabang Karawaci (Susanto \& Halim, 2020). Penelitian oleh Fachrezi \& Khair (2020) mengenai pengaruh langsung dan tidak langsung antara Komunikasi, Motivasi dan Lingkungan Kerja terhadap Kinerja Karyawan di PT. Angkasa Pura II (Persero) Kantor Cabang Kualanamu dengan hasil ada pengaruh dan signifikan antara variabel lingkungan kerja dan motivasi terhadap kinerja (Fachrezi \& Khair, 2020). yang terakhir penelitian oleh Fereddy Siagian (2020) Pengaruh Lingkungan Kerja Terhadap Kinerja Tenaga Kependidikan di Akademi Maritim Cirebon dengan hasil ingkungan kerja sangat berpengaruh terhadap kinerja tenaga kependidikan ( $\mathrm{F}$. Siagian, 2020).

Berdasarkan penelitian sebelumnya, masih sedikit penelitian yang menganalisis pengaruh lingkungan kerja terhadap kinerja tenaga kependidikan. Oleh karena itu, penelitian ini bertujuan untuk meneliti lebih lanjut mengenai pengaruh lingkungan kerja terhadap kinerja tenaga kependidikan pada Fakultas Matematika dan Ilmu Pengetahuan Alam Universitas Lampung.

\section{METODE PENELITIAN}

Metode penelitian ini adalah kuantitatif deskriptif. Lokasi penelitian dilakukan di pada Fakultas Matematika dan Ilmu
Pengetahuan Alam (FMIPA) Universitas Lampung Lokasi Jl. Soemantri Brojonegoro No. 1, Kelurahan Gedong Meneng, Kecamatan Rajabasa, Bandar Lampung. Variabel penelitian ini adalah Lingkungan Kerja (X) dan Kinerja Karyawan (Y). Teknik pengumpulan data dalam penelitian ini menggunakan kuesioner, observasi, dan dokumentasi.

Populasi dalam penelitian ini adalah tenaga kependidikan yang ada di Fakultas Matematika dan Ilmu Pengetahuan Alam (FMIPA) Universitas Lampung yang berjumlah 76 orang dengan rincian sebagai berikut:

Tabel 1. Data Tenaga Kependidikan FMIPA Unila

\begin{tabular}{clc}
\hline No & \multicolumn{1}{c}{ Keterangan } & Total \\
\hline 1 & Pegawai Negeri Sipil & 44 \\
2 & Tenaga Kontrak & 32 \\
\hline & Total & 76 \\
\hline
\end{tabular}

Penentuan sampel menggunakan metode Purposive Sampling sehingga didapat sampel berjumlah 44 orang tenaga kependidikan. metode yang digunakan untuk membuktikan kebenaran data-data yang akan di analisis dengan cara menguji data menggunakan program SPSS. Analisis data pada penelitian ini menggunakan uji-t untuk menguji hipotesis apakah Lingkungan Kerja (X) berpengaruh terhadap Kinerja Karyawan (Y) dengan hipotesisnya sebagai berikut:

$\mathrm{H}_{0}$ : tidak ada pengaruh antara Lingkungan Kerja (X) terhadap Kinerja Karyawan (Y).

$\mathrm{Ha}$ : terdapat pengaruh antara Lingkungan Kerja (X) terhadap Kinerja Karyawan (Y).

Pengambilan keputusan dilakukan dengan melihat nilai signifikansi pada tabel Coefficients. Dasar pengujian hasil regresi dilakukan dengan tingkat kepercayaan sebesar $95 \%$ atau dengan taraf signifikannya sebesar $5 \% \quad(\alpha=0,05)$. Adapun kriteria dari uji statistik t:

Jika nilai signifikansi uji $\mathrm{t}>0,05$ maka $\mathrm{H}_{0}$ diterima dan $\mathrm{Ha}$ ditolak. Artinya tidak 
ada pengaruh antara Lingkungan Kerja (X) terhadap Kinerja Karyawan (Y).

Jika nilai signifikansi uji $\mathrm{t}<0,05$ maka $\mathrm{H}_{0}$ ditolak dan $\mathrm{Ha}$ diterima. Artinya terdapat pengaruh antara Lingkungan Kerja (X) terhadap Kinerja Karyawan (Y).
Dari data yang didapat lalu dianalisis menggunakan uji $\mathrm{t}$ untuk menguji hipotesis apakah Lingkungan Kerja (X) berpengaruh terhadap Kinerja Karyawan (Y) sehingga mendapatkan hasil sebagai berikut:

\section{HASIL DAN PEMBAHASAN}

Tabel 2. Hasil Uji Hipotesis

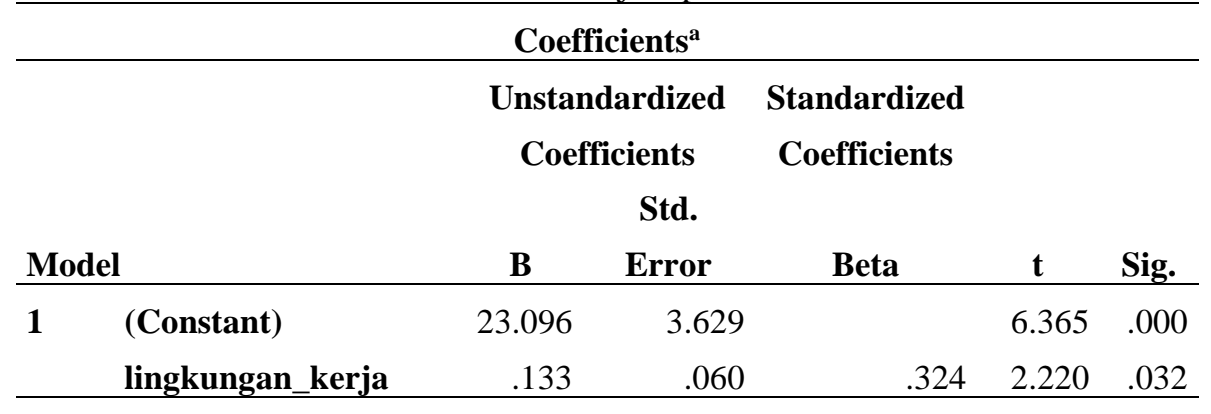

a. Dependent Variable: kinerja_karyawan

Berdasarkan tabel 2, didapat nilai Sig. sebesar $0.032<0.05$ maka $\mathrm{H}_{0}$ ditolak dan Ha diterima. Artinya terdapat pengaruh antara Lingkungan Kerja (X) terhadap Kinerja Karyawan (Y).

Selain, itu didapat pula nilai B untuk Constants sebesar 23,096 dan Lingkungan Kerja (X) sebesar 0,133, sehingga persamaan regresi linear dapat ditulis:

$\mathrm{Y}=23,096+0,133 \mathrm{X}$

Persamaan di atas dapat diartikan konstanta sebesar 23,096 memiliki makna bahwa nilai konsisten variabel kinerja tenaga kependidikan sebesar 23,096. Koofisien regresi $\mathrm{X}$ sebesar 0,133 mengandung arti bahwa setiap penambahan $1 \%$ nilai lingkungan kerja, maka nilai kinerja tenaga kependidikan bertambah sebesar 0,133. Nilai tersebut bernilai positif, sehingga dapat diketahui bahwa arah pengaruh lingkungan kerja terhadap kinerja tenaga kependidikan adalah positif.

Kemudian besar pengaruh lingkungan kerja (X) terhadap kinerja karyawan (Y) dilakukan uji determinasi sebagai berikut:

Tabel 3. Hasil Uji Koefisien Determinasi

\begin{tabular}{lcccr}
\hline \multicolumn{5}{c}{ Model Summary } \\
\hline Model & R & R Square & Square & $\begin{array}{c}\text { Adjusted R } \\
\text { the Estimate }\end{array}$ \\
\hline $\mathbf{1}$ & $.324^{\mathrm{a}}$ & .105 & .084 & 2.99027 \\
\hline a. Predictors: (Constant), lingkungan_kerja & & \\
\hline
\end{tabular}

Dari Tabel 3. didapatkan hasil output pada Model Summary untuk nilai korelasi/ hubungan $(\mathrm{R})$ sebesar 0,324 dan koefisien determinasi $\left(R^{2}\right)$ sebesar 0,105. sehingga dari nilai tersebut dapat dijelaskan bahwa sebesar $10,5 \%$ kinerja tenaga kependidikan yang ada di Fakultas Matematika dan Ilmu
Pengetahuan Alam (FMIPA) Universitas Lampung dipengaruhi oleh variabel lingkungan kerja dan sisanya sebesar 89,5\% dipengaruhi variabel lain yang tidak diterangkan dalam penelitian ini.

KESIMPULAN 
Berdasarkan hasil didapat nilai Sig. sebesar $0.032<0.05$ maka $\mathrm{H}_{0}$ ditolak dan Ha diterima. Artinya terdapat pengaruh positif antara Lingkungan Kerja (X) terhadap Kinerja Karyawan (Y). Hasil uji koefisien determinasi (R2) sebesar 0,105, sehingga sebesar $10,5 \%$ kinerja tenaga kependidikan yang ada di Fakultas Matematika dan Ilmu Pengetahuan Alam (FMIPA) Universitas Lampung dipengaruhi oleh variabel lingkungan kerja dan sisanya sebesar $89,5 \%$ dipengaruhi variabel lain yang tidak diterangkan dalam penelitian ini.

\section{DAFTAR PUSTAKA}

Anam, K., \& Rahardja, E. (2017). Pengaruh Fasilitas Kerja, Lingkungan Non Fisik dan Kepuasan Kerja Terhadap Kinerja Karyawan (Studi Pada Pegawai Dinas Perindustrian dan Perdagangan Jawa Tengah). Diponegoro Journal of Management, 6(4), 1-11. http://ejournals1.undip.ac.id/index.php/dbr

Aspiyah, M., \& Martono, S. (2016). Pengaruh Disiplin Kerja, Lingkungan Kerja dan Pelatihan pada Produktivitas Kerja. Management Analysis Journal, 5(4), 339-346. https://doi.org/10.15294/maj.v5i4.127 12

Budianto, A. A. T., \& Katini, A. (2015). Pengaruh Lingkungan Kerja Terhadap Kinerja Pegawai Pada PtT Perusahaan Gas Negara (Persero) Tbk SBU Distribusi Wilayah I Jakarta. KREATIF: Jurnal Ilmiah Prodi Manajemen Universitas Pamulang, 3(1), 100-124. https://doi.org/10.37751/parameter.v4 i 2.42

Edasa, D., \& Putra, E. E. (2015). PENGARUH GAYA KEPEMIMPINAN, LINGKUNGAN KERJA DAN MOTIVASI KERJA TERHADAP KINERJA PEGAWAI LPP-RRI BUKITTINGGI Oleh: Defri Edasa dan Elsanra Eka Putra. Jurnal
Riset Manajemen Bisnis Dan Publik, 3(2).

Fachrezi, H., \& Khair, H. (2020). Pengaruh Komunikasi, Motivasi dan Lingkungan Kerja Terhadap Kinerja Karyawan Pada PT. Angkasa Pura II (Persero) Kantor Cabang Kualanamu. Maneggio: Jurnal Ilmiah Magister Manajemen, 3(1), 107-119. https://doi.org/10.30596/maneggio.v3 i1.4834

Farizki, M. R., \& Wahyuati, A. (2017). Pengaruh Motivasi Dan Lingkungan Kerja Terhadap Kinerja Karyawan Medis. Jurnal Ilmu Dan Riset Manajemen, 6(5), 1-16. https://doi.org/10.31602/alkalam.v4i1.830

Fatria, Y., \& Hifnie, I. Z. (2020). Pengaruh Budaya Organisasi Dan Lingkungan Kerja Terhadap Kinerja Pegawai Pada Kantor Kelurahan Pasar Banjit Kabupaten Way Kanan. Jurnal Ilmu Manajemen Saburai, 6(1), 61-68.

Ferawati, A. (2017). Pengaruh Lingkungan Kerja Dan Disiplin Kerja Terhadap Kinerja Karyawan. Jurnal Agora, $5(1)$.

http://eprints.uny.ac.id/41801/1/Adity aNurPratama_12808144059.pdf

Handayani, S., \& Daulay, R. (2021). Analisis Pengaruh Lingkungan Kerja dan Stress Kerja Terhadap Kinerja Karyawan. Seminar Nasional Teknologi Edukasi Sosial Dan Humaniora, 1(1), 544-548. https://doi.org/10.35316/idarah.2020. v1i1.16-29

Josiah, T. (2020). Pengaruh Motivasi dan Disiplin Terhadap Peningkatan Kinerja Pegawai di Dinas Pendidikan dan Kebudayaan Kabupaten Pesisir Barat. Jurnal Ilmu Manajemen Saburai, 6(1), 53-60.

Mudayana, A. A. (2020). Pengaruh Motivasi dan beban kerja terhadap Kinerja Karyawan di Rumah Sakit Nur Hidayah Bantul. Kes Mas: Jurnal Fakultas Kesehatan Masyarakat 
Universitas Ahmad Daulan, 4(2), 8492.

http://www.jogjapress.com/index.php /KesMas/article/viewFile/1173/589

Nabawi, R. (2019). Pengaruh Lingkungan Kerja, Kepuasan Kerja dan Beban Kerja Terhadap Kinerja Pegawai. Maneggio: Jurnal Ilmiah Magister Manajemen, 2(2), 170-183. https://doi.org/10.30596/maneggio.v2 i 2.3667

Sambodo, A., Kuncoro, D. K. R., \& Gunawan, S. (2020). Analisis Mitigasi Risiko Operasional Kontra Bank Garansi PT. Asuransi Kredit Indonesia Kantor Cabang Balikpapan Berbasis ISO31000. Journal Industrial Servicess, 5(2), 147-155. https://doi.org/10.36055/jiss.v5i2.799 2

Siagian, F. (2020). Pengaruh Lingkungan Kerja Terhadap Kinerja Tenaga Kependidikan di Akademi Maritim Cirebon. Jurnal Kependidikan: Jurnal Hasil Penelitian Dan Kajian Kepustakaan Di Bidang Pendidikan, Pengajaran Dan Pembelajaran, 6(2), 259-265.

https://doi.org/10.33394/jk.v6i2.2581

Siagian, T. S., \& Khair, H. (2018). Pengaruh Gaya Kepemimpinan Dan Lingkungan Kerja Terhadap Kinerja Karyawan Dengan Kepuasan Kerja Sebagai Variabel Intervening. Maneggio: Jurnal Ilmiah Magister Manajemen, 1(1), 59-70. https://doi.org/10.30596/maneggio.v1 i1.2241

Sunarsi, D., Wijoyo, H., Prasada, D., \& Andi, D. (2020). Pengaruh Lingkungan Kerja Terhadap Kinerja Karyawan Pada Pt. mentari Persada di Jakarta. Seminar Nasional Manajemen, Ekonomi Dan Akuntansi., $\quad$ 117-123. https://doi.org/10.37950/wbaj.v2i1.91 6

Susanto, S., \& Halim, I. (2020). Pengaruh Human Relation Dan Lingkungan
Kerja Terhadap Kinerja Karyawan Pada PT. Kompas Gramedia Cabang Karawaci. Proceedings Universitas ..., 158-170. http://www.openjournal.unpam.ac.id/i ndex.php/Proceedings/article/view/42 53

Syafrina, N., \& Manik, S. (2018). Pengaruh Lingkungan Kerja Terhadap Kinerja Karyawan Pada Pt. Bank Syariah Mandiri. Al-Masraf: Jurnal Lembaga Keuangan Dan Perbankan, 3(2), 181-191.

Wijaya, H., \& Susanty, E. (2017). Pengaruh Lingkungan Kerja Terhadap Kinerja Pegawai Pada Instansi Pemerintah Daerah Kabupaten Musi Banyuasin (Studi Kasus Dinas Pertambangan Dan Energi Kabupaten Musi Banyuasin). Jurnal Ecoment Global, 2(1), 40-50. https://doi.org/10.35908/jeg.v2i1.213 Wildayati, R., Solahudin, D., \& Rahman, A. (2019). Optimalisasi Pelayanan Haji dalam Meningkatkan Kepuasan Jamaah. Anida (Aktualisasi Nuansa Ilmu Dakwah), 17(2), 165-182. https://doi.org/10.15575/anida.v17i2. 5061

Yamin, Y. (2017). PENGARUH TEKANAN KERJA TERHADAP KINERJA KARYAWAN PADA PERUSAHAAN DAERAH AIR MINUM (PDAM) KABUPATEN PESAWARAN. Ekombis Sains: Jurnal Ekonomi, Keuangan Dan Bisnis, 2(2), 221-240.

Yamin, Y., Nuzleha, \& Hidayat, R. R. (2021). Hubungan Kesejahteraan Karyawan dengan Kinerja Karyawan. Jurnal Manajemen Mandiri Saburai, $5(2)$, 143-152. http://eprints.polsri.ac.id/746/3/File 3 \%28BAB II\%29.pdf

Yuliantari, K., \& Prasasti, I. (2020). Pengaruh Lingkungan Kerja Terhadap Kinerja Karyawan Pada LLDIKTI Wilayah III Jakarta. Widya Cipta: Jurnal Sekretari Dan 
Fakultas Ekanami Universitas Sang Bumi Ruwa Jurai

Dengan tema "Strategi Pengelalaan Sumker Daya Daerah dalam Menciptakan Gaad Gavernance"

Manajemen, $\quad 4(1), \quad 76-82$.

https://doi.org/10.31294/widyacipta.v

$4 \mathrm{i} 1.7699$ 